\title{
CONSTRAINTS ON THE GEOLOGIC HISTORY OF THE KARST SYSTEM IN SOUTHERN MISSOURI, U.S.A. PROVIDED BY RADIOGENIC, COSMOGENIC AND PHYSICAL/CHEMICAL CHARACTERISTICS OF DOLINE FILL
}

\author{
POVEZAVA MED GEOLOŠKO ZGODOVINO IN KRAŠKIM \\ SISTEMOM V JUŽNEM MISSOURIJU ZDA S POMOČJO \\ RADIOGENIH, KOZMOGENIH IN FIZIKALNO-KEMIJSKIH \\ ZNAČILNOSTI ZAPOLNITVE VRTAČE
}

DAVID J. WEARY ${ }^{1} \&$ RICHARD W. HARRISON ${ }^{1} \&$ MARIA P. WRIGHT $^{2} \&$ ROBERT B. JACOBSON ${ }^{3} \&$ MILAN J. PAVICH ${ }^{1} \&$ SHANNON A. MAHAN ${ }^{4} \&$ DAVID J. WRONKIEWICZ ${ }^{5}$

\footnotetext{
${ }^{1}$ U.S. Geological Survey, MS 926A, Reston, VA 20192, USA, e-mail: dweary@usgs.gov

${ }^{2}$ Center for Water and Environmental Sustainability, Oregon State University 210 Strand Ag Hall, Corvallis, OR 97331, USA

${ }^{3}$ U.S. Geological Survey, Columbia Research Center, 4200 New Haven Road, Columbia, MO 65201, USA

${ }^{4}$ U.S. Geological Survey, Box 25046, MS 974, Denver Federal Center, Denver, CO 80225-0046, USA

${ }^{5}$ Department of Geology and Geophysics, University of Missouri Rolla, 159 McNutt Hall, 1870 Miner Circle, Rolla, MO 65409-0410, USA
} 


\begin{abstract}
UDC: 551.73:551.44(77)

David J. Weary \& Richard W. Harrison \& Maria P. Wright \& Robert B. Jacobson \& Milan J. Pavich \& Shannon A. Mahan \& David J. Wronkiewicz: Constraints on the geological history of the karst system in southern Missouri, U.S.A. provided by radiogenic, cosmogenic and physical/chemical characteristics of doline fill
\end{abstract}

The Ozark Plateaus region of southern Missouri is underlain by dominantly carbonate marine platform rocks of Paleozoic age. The region has been sub-aerially exposed since the late Paleozoic and is characterized by extensive karst. To better understand the geologic history of this regional karst system, we examined the stratigraphic record preserved in the fill of a large doline near the largest spring in the region. Samples of fill from natural exposures and drill core were analyzed using thermoluminescence (TL) and 10Be cosmogenic techniques, and the physical/chemical characteristics of the fill material were determined by visual inspection, X-ray analyses, and grain-size measurements. Drill-hole data indicate that the allochthonous doline fill is $36.3 \mathrm{~m}$ thick and rests on at least $15.6 \mathrm{~m}$ of cave breakdown and sediment. The doline fill is divisible into 7 zones. Analysis of $10 \mathrm{Be}$ concentrations suggest that the entire doline fill was derived from local residuum during the middle (Illinoian) to late Pleistocene (Wisconsinan). X-ray diffraction analyses of clays throughout the doline fill indicate that they consist of nearly equal amounts of kaolinite and illite, consistent with terrestrial weathering.

Key words: Ozarks, Missouri, karst, cosmogenic, thermoluminiscence, USA.

Izvleček

UDC: 551.73:551.44(77)

David J. Weary \& Richard W. Harrison \& Maria P. Wright \& Robert B. Jacobson \& Milan J. Pavich \& Shannon A. Mahan \& David J. Wronkiewicz: Povezava med geološko zgodovino in kraškim sistemom v južnem Missouriju ZDA s pomočjo radiogenih, kozmogenih in fizikalno-kemijskih značilnosti zapolnitve vrtače

Območje Ozarkov v južnem Missouriju gradijo predvsem karbonatne, morske, platformne kamnine paleozojske starosti. Teren, ki vsebuje obširen kras, predstavlja kopno že od poznega Paleozojka. Da bi bolje razumeli geološko zgodovino tega kraškega sistema, smo raziskali stratigrafske podatke ohranjene v zapolnitvi velike vrtače pri največjem izviru v okolici. Vzorci zapolnitve iz naravnih izdankov in iz vrtine so bili analizirani s termoluminiscenco (TL) in 10Be kozmogeno metodo. Fizikalno-kemijske značilnosti zapolnitve so bile določene vizualno, z rentgensko metodo in merjenjem velikosti delcev. Podatki vrtine kažejo, da je debelina alohtonega materiala, ki zapolnjuje vrtačo $36,3 \mathrm{~m}$. Ta material prekriva podorne bloke in sedimente debeline vsaj 15,6 m. Glede na teksturo, strukturo in barvo delimo material, ki zapolnjuje vrtačo na 7 con. Analize 10Be koncentracij kažejo, da material za celotni stolpec zapolnitve izvira iz rezidualnega materiala iz srednjega (Illinoian) in zgornjega Pleistocena (Wisconsian). Rentgenske analize glin kažejo, da zapolnitev vrtače vsebuje enake količine kaolinita in illita, kar je skladno z zemeljskim preperevanjem.

Ključne besede: kras, kozmogenija, Ozark, Missouri, ZDA. 


\section{INTRODUCTION}

The classical approach to determining the history and chronology of geologic events involves analyzing a preserved depositional record; this is inherently difficult in karst because of the predominance of dissolution and chemical removal of material from the system. However, deposits that have collapsed, washed, or blown into large dolines can be suitable for providing absolute and relative age constraints for karst systems.

The Ozark Plateaus region of southern Missouri (Fig. 1) is underlain by dominantly carbonate marine platform rocks of Paleozoic age. The region has been sub-aerially exposed since the late Paleozoic and is characterized by extensive karst; it hosts a spring system that is unparalleled in North America in numbers, discharge, and scenic beauty. As a result of reversals in direction of hydrologic gradient, uplift and stream incision, and large fluctuations in water flow since the late Paleozoic, this karst system is extremely complex and its geologic history is poorly understood.

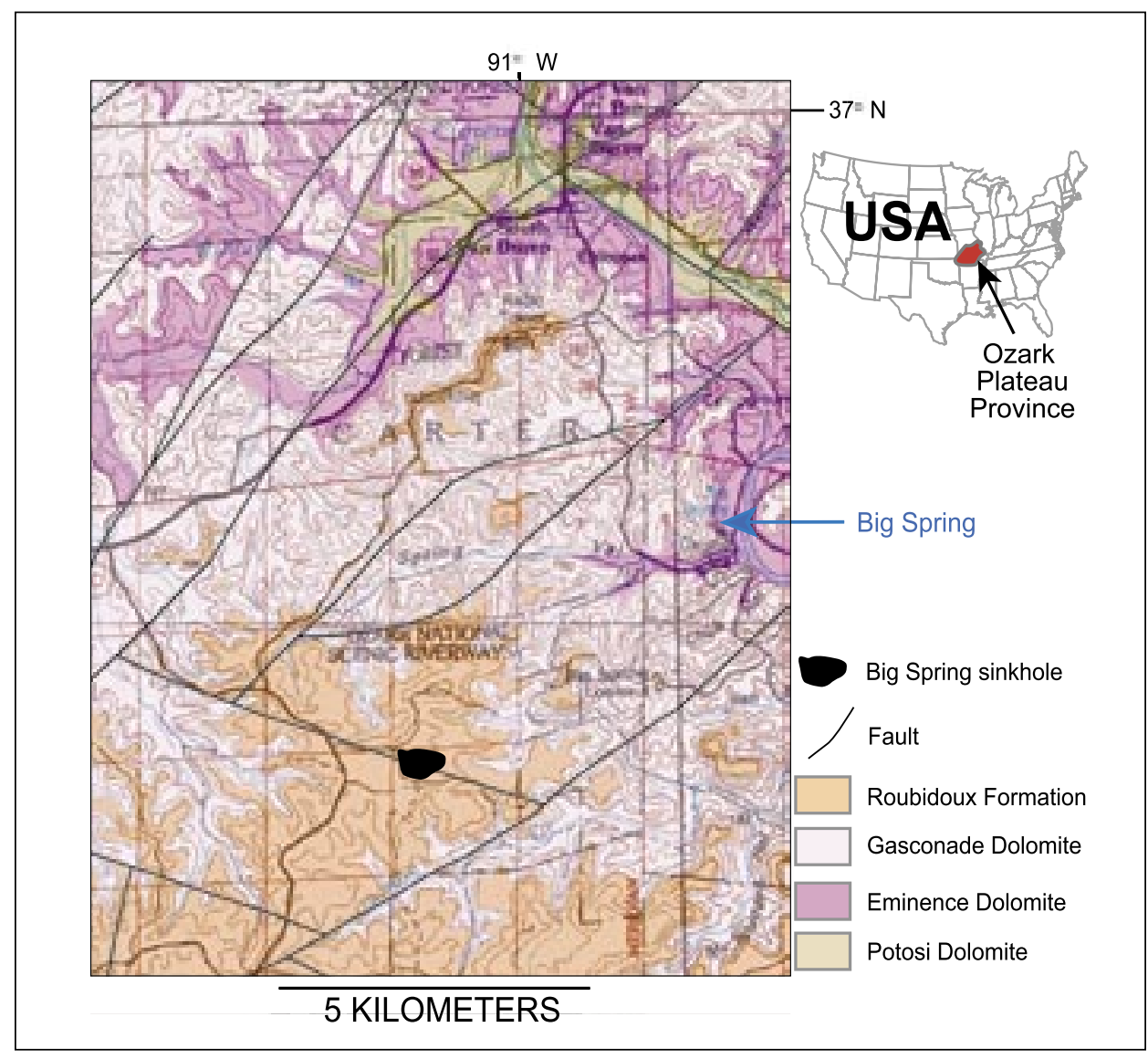

Fig. 1: Location of Big Spring sinkhole and geology of the study area. The bedrock is chiefly Cambrian and Lower Ordovician dolomite, quartz sandstone, and chert. Geology from Weary and Schindler, 2004. 


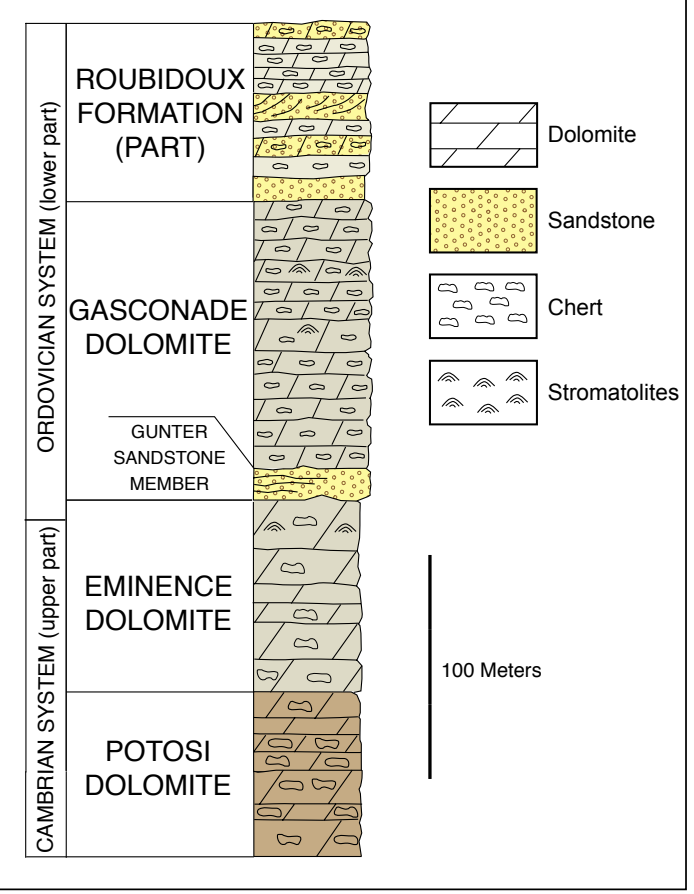

Fig. 2: Stratigraphic column of rocks exposed in the study area in southern Missouri.

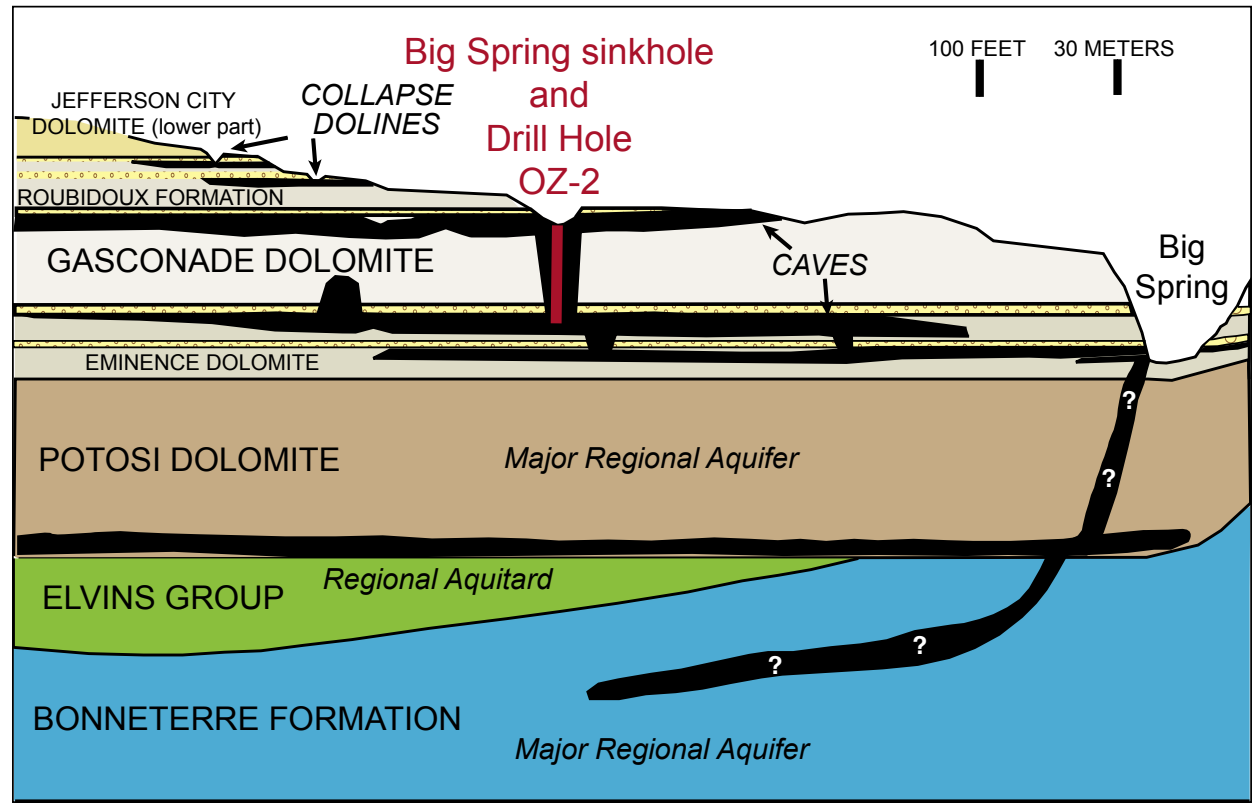

Fig. 3: Generalized conceptual model of cave and doline distribution within the stratigraphy of the study area. 
David J. Weary et al.: Constraints onthe geological history of the karst system in southern Missouri, U.S.A. provided ...

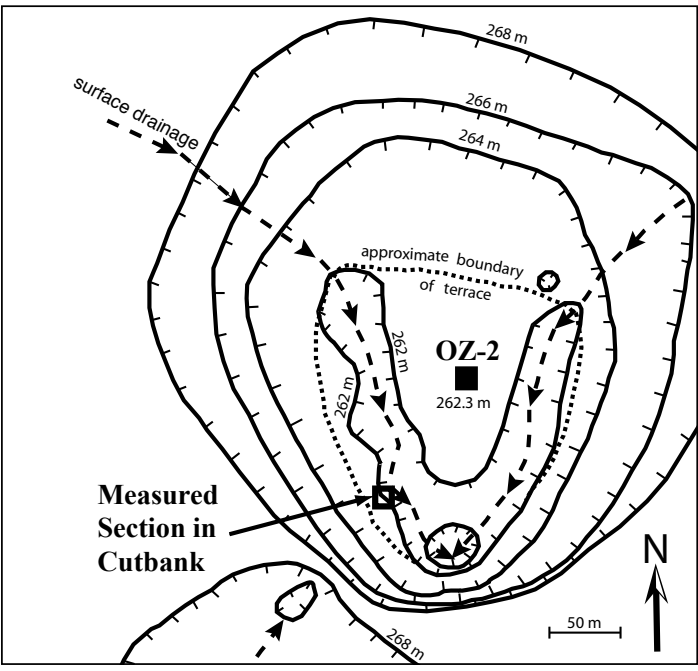

Fig. 4: Plan view of Big Spring sinkhole and location of drill hole (OZ-2) and measured section in cutbank.

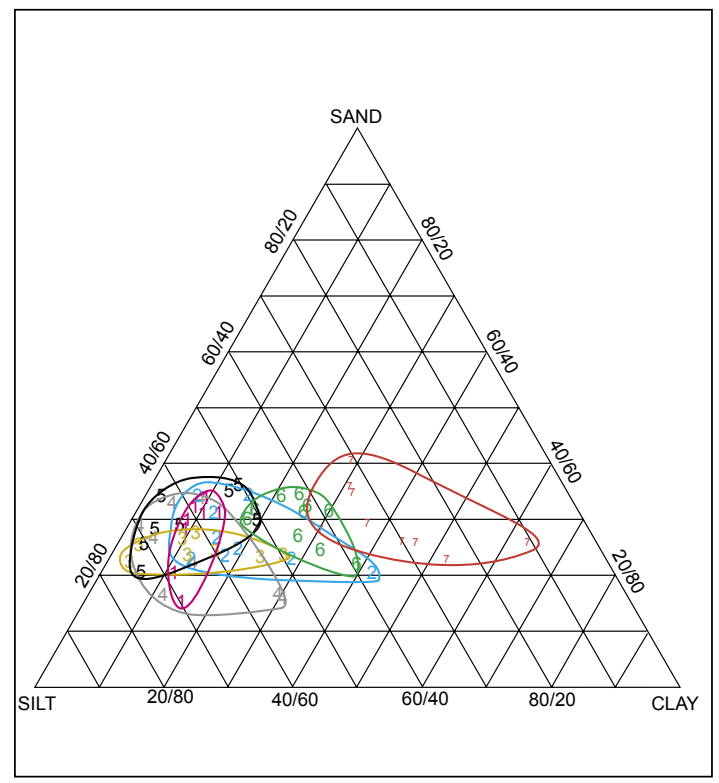

Fig. 5: Ternary diagram showing grain size distribution for matrix samples from drill hole OZ-2, grouped by zone.
In an effort to better understand the geologic history of this karst system, we looked at the stratigraphic record preserved in the fill of a large doline, known as the Big Spring sinkhole, which is in proximity to Big Spring, the largest spring in the region (Fig. 1). Samples of fill from natural exposures and drill core were analyzed for age, etc., using thermoluminescence (TL) and ${ }^{10} \mathrm{Be}$ cosmogenic techniques, and the physical/chemical characteristics of the fill material were determined by visual inspection, X-ray analyses, and grain-size measurements. Combined, these analyses provide constraints on doline development and karst history.

\section{GEOLOGIC SETTING}

The exposed bedrock in the study area is Upper Cambrian and Lower Ordovician dolomite and sandstone (Fig. 1, Fig 2). Bedding is nearly horizontal with a slight regional dip towards the south. Strike-slip faults with small vertical displacement are the most common structures in the area. Development of the Big Spring sinkhole, which is unusually large for this area, may be related to one of these faults (Fig. 1). The bedrock over most of the area is covered by a thick residuum derived from the insoluble components of the dolomite and sandstone bedrock, chiefly gravel, cobbles, and boulders of chert, quartz sandstone, and orthoquartzite. The entire area is karstified with abundant dolines, caves, and springs. Caves are developed chiefly in the dolomite units and beneath sandstone horizons (Orndorff et al, 2002; 2003) (Fig. 3). Many of the dolines are formed by collapse of the sandstones that form the roofs of many of the caves. 


\section{PHYSICAL DESCRIPTION}

The map view of Big Spring sinkhole is subcircular and measures approximately $400 \mathrm{~m}$ wide in the east-west dimension and about $400 \mathrm{~m}$ in the north-south dimension (Fig. 4). The topographic depression is about 10 meters deep. Drill-hole data indicate that the doline fill is $36.3 \mathrm{~m}$ thick and rests conformably on at least $15.6 \mathrm{~m}$ of cave fill giving a combined depth of the hole in the bedrock of at least $61.9 \mathrm{~m}$. A relatively flat depositional terrace composed of soil and residual bedrock pebbles occupies the south-central part of the doline. Two intermittent surface streams converge in the southern, deepest, part of the doline where water sinks into a rubble- and soil-choked throat. The streams have incised channels into the doline fill up to $3 \mathrm{~m}$ deep. Core was taken from a hole, designated OZ-2, drilled near the center of the doline (Fig. 4).

The doline fill is divisible into 7 zones, based on textural, structural, and color variations (Table 1). The upper zone is a soil comprising loess and reworked loess and is about 1 to $2 \mathrm{~m}$ thick. Underlying this is an altered, reddish-brown clayey silt zone, as much as $6.3 \mathrm{~m}$ thick. The $3^{\text {rd }}$ zone ( $4.6 \mathrm{~m}$ thick $)$ consists of pale-brown clayey silt and is underlain by the $4^{\text {th }}$ zone $(\sim 6.7 \mathrm{~m}$ thick $)$ of light-gray silty clay. The $5^{\text {th }}$ and $6^{\text {th }}$ zones $(\sim 10.1 \& \sim 7.3 \mathrm{~m}$ thick $)$ consist of pink and deep-red silty clay, respectively; their boundary is gradational and both zones contain millimeter-scale laminations and localized cross bedding. The $7^{\text {th }}$ zone is sandy and silty clay and clayey and silty sand with angular clasts up to boulder size.

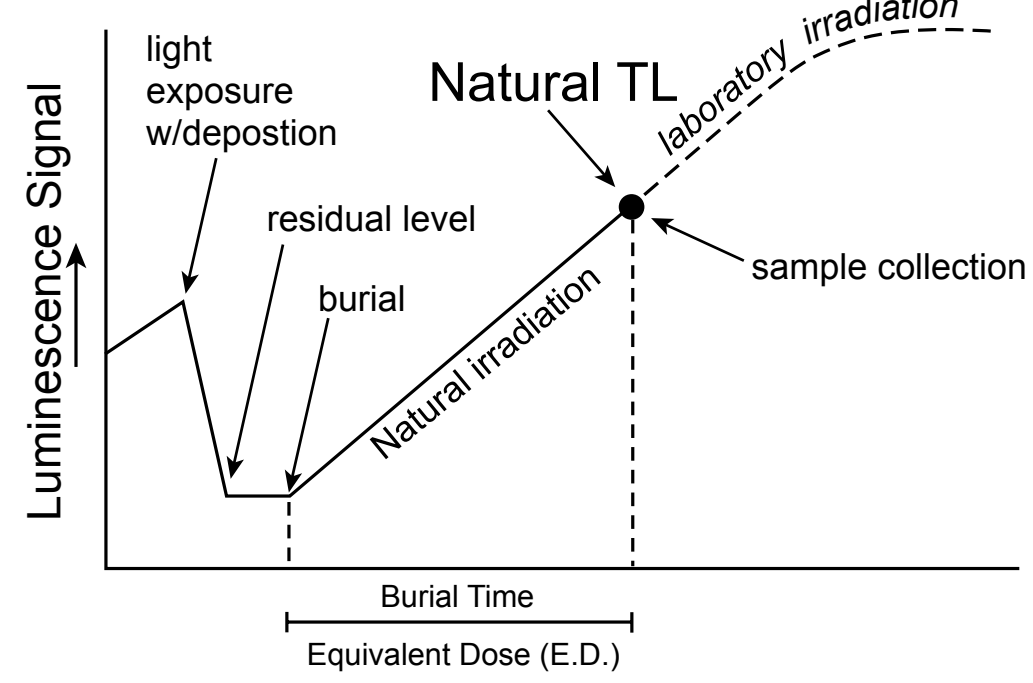

Fig. 6: Diagrammatic representation of the Thermoluminescence (TL) geological cycle. Light exposure reduces the TL signal of sediment to a low definable level (residual level). After burial of the sediment, ionizing radiation progressively imparts a TL signal. The TL signal at the time of collection is termed the natural TL. Beta doses added to the natural TL signal defines a function, which is often the basis for determining the equivalent dose (burial time) (Forman et al., 2000, Figure modified from Wintle and Huntley, 1982). 


\section{GRAIN SIZE ANALYSIS}

Results of grain size analysis of samples of matrix taken from the core are shown on Figure 5. This analysis excludes larger than sand-size clasts that occur throughout the core. Most samples from zones 1-5 are sandy-silt. Samples from zone 6 are more clay-rich and those from zone 7 are silty sandy clay and clayey silty sand. The results for zones 1-6 are consistent with weathering products derived from the quartz sand and dolomite of the Roubidoux Formation, the locally exposed bedrock. Based on the change in grain size of the matrix, large angular cobbles and intersection of voids filled with water encountered during drilling, the sediment in zone 7 is interpreted to be cave deposits and breakdown.

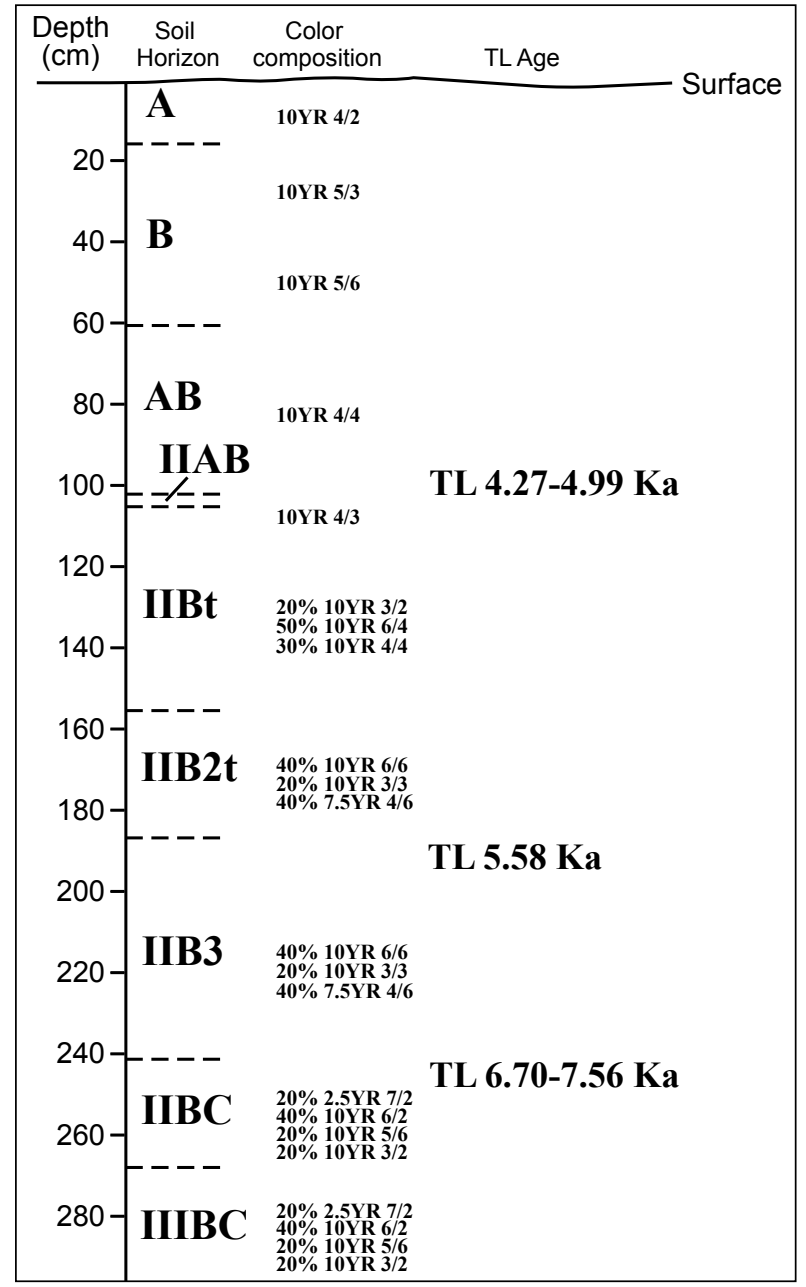

Fig. 7: Soil horizons and colors observed in the cutbank of Big Spring sinkhole along with Thermoluminescence (TL) sample depths and ages.

\section{X-RAY DIFFRACTION ANALYSIS}

$\mathrm{X}$-ray diffraction analyses of clays throughout the doline fill indicate that they consist of about equal amounts of kaolinite and illite (Erickson and al, 2002). This precludes any primary marine contribution and suggests deposition in an acidic and humid terrestrial environment. Such conditions have been extant in the region since the Pennsylvanian.

\section{RELATIVE AGES}

The loess in zone 1 correlates with the Peoria Loess which was deposited 22,000 to 12,500 years B.P (Willman and Frye, 1970). during the late Wisconsinan (Wurm). The alteration of the reddish-brown clay zone (zone 2) is tentatively correlated with the Sangamon Soil which is approximately 125,000 to 75,000 years old. This soil was produced during the Sangamon interglacial (Riss-Wurm); thus the material is constrained as Illinoian (Riss) or older. Samples of the 4th zone, 
analyzed for fossil pollen were barren. However, subrounded pebbles of black, maroon, and red chert were recovered from this zone; no such colored cherts exist in the local stratigraphic section. Our interpretation is that these 'exotic' pebbles are representative of relic Mississippian rocks that once covered the area. The Pierson Limestone that crops out in Green County, Missouri, about $200 \mathrm{Km}$ to the west and contains black and red chert is one possible source for the clasts (Thompson, 1995).

\section{THERMOLUMINESENCE AGES}

Thermoluminescence (TL) is a process in which a mineral emits light, under heating to $500^{\circ} \mathrm{C}$ or exposure to infrared light, due to the recombination of charges trapped at metastable defect sites within the mineral lattice. The amount of light emitted is proportional to energy absorbed by the mineral as a result of its previous exposure to ionizing radiation from radioactive elements in the buried environment and the mineral's intrinsic sensitivity to radiation. Exposure of the mineral to sunlight reduces or bleaches the TL signal to a definable low level called the residual level (Fig 6). If the grain is then deposited and buried away from light, it will begin to accumulate defect sites and a progressively higher TL signal that is proportional to the burial time (Fig. 6). Thus, unlike radioactive decay, in TL, the post depositional clock (signal) is ticking up instead of ticking down. Comparisons made of the light emitted by a natural sample and the amount of light emitted by a sample with a known added radiation dose, plus separate dosimetry measurements, allow calculation of the time since the sample was last exposed to a clock-resetting event (exposure to light or heat) (Fig. 6). TL analyses of samples taken from depths of about $1,1.9$, and 2.4 meters in a cut bank incised into the doline fill (Fig. 4) indicate TL ages of the reworked loess ranging from 7.6 to 4.3 thousand years B.P (Fig. 7). This reworked loess interval is equivalent to zone 1 in the core (Table 1).

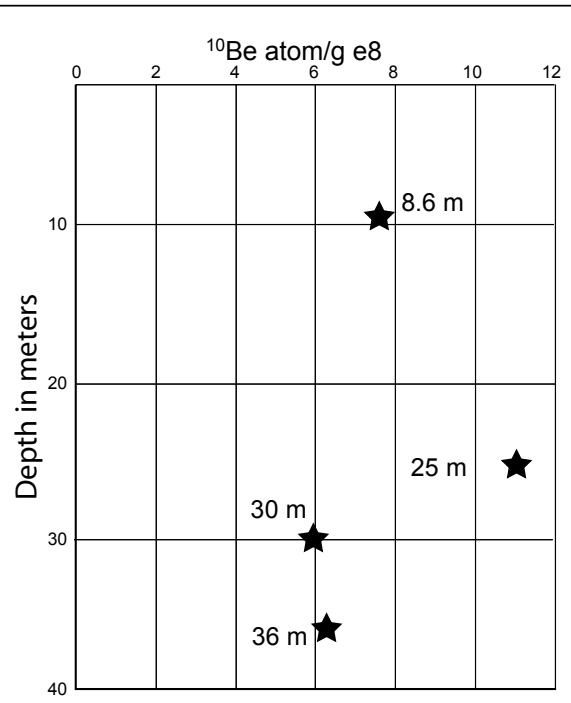

Fig 8: Depth and concentration of ${ }^{10} \mathrm{Be}$ in samples from drill hole OZ-2. 


\section{COSMOGENIC ${ }^{10} \mathrm{BE}$ AGES}

${ }^{10} \mathrm{Be}$ found at the earth's surface is dominantly produced by cosmic ray spallation of ${ }^{16} \mathrm{O}$ or negative muon capture by ${ }^{16} \mathrm{O}$ in the atmosphere, and delivered to the earth's surface by rainfall (thus, referred to as meteoric ${ }^{10} \mathrm{Be}$ ) where it is adsorbed chemically to clays and iron oxides in soils. Once buried, these particles lose ${ }^{10} \mathrm{Be}$ through radioactive decay with a half-life of $1.5 \mathrm{Myr}$.

The concentration of meteoric ${ }^{10} \mathrm{Be}$ in soil and sediment can be measured by Accelerator Mass Spectrometry (AMS) after chemical processing. The processing involves weighing a dried sample (typically less than a gram contains sufficient ${ }^{10} \mathrm{Be}$ ), adding a known weight of ${ }^{9} \mathrm{Be}$, treating with $\mathrm{HClO}_{4}$ to oxidize organic material, dissolving the inorganic residue with $\mathrm{HCl}$, precipitating $\mathrm{Be}$, $\mathrm{Al}$ and $\mathrm{Fe}(\mathrm{OH})_{3}$ (using $\mathrm{NH}_{4} \mathrm{OH}$ ) and separating $\mathrm{Be}$ from $\mathrm{Fe}$ and $\mathrm{Al}$ using $\mathrm{HF}$ to produce a soluble $\mathrm{BeF}$ complex. $\mathrm{Be}(\mathrm{OH})$ is precipitated from this solution and heated to convert to $\mathrm{BeO}$. The $\mathrm{BeO}$ target contains the unknown ${ }^{10} \mathrm{Be}$, and the ${ }^{10} \mathrm{Be} /{ }^{9} \mathrm{Be}$ ratio is measured by AMS. Details of beryllium

\begin{tabular}{|c|c|c|c|}
\hline Zone & $\begin{array}{l}\text { Depth } \\
\text { (molers tolow } \\
\text { surtace) }\end{array}$ & Tentural Description & Other descriptions \\
\hline t. Soll and bess & 0.1 .3 & 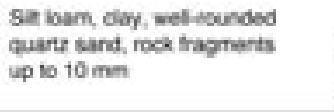 & 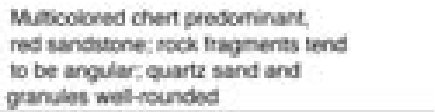 \\
\hline $\begin{array}{l}\text { 2- Nhered, redduh- } \\
\text { bowelapey sin more }\end{array}$ & 137.6 & 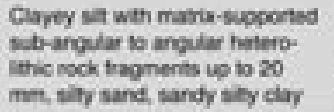 & 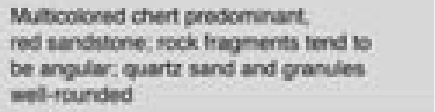 \\
\hline $\begin{array}{l}\text { 3- Pabe-trown clayey, } \\
\text { sit zone loossiby } \\
\text { includes lowss? }\end{array}$ & $w_{0}^{76-12.2}$ sample 8 en & $\begin{array}{l}\text { Sandy ciryery shat and silty clay } \\
\text { with nock tragneres up os } 8 \mathrm{~mm}\end{array}$ & 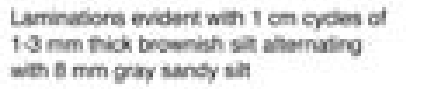 \\
\hline $\begin{array}{l}\text { 4-Gray clayer at } \\
\text { zone }\end{array}$ & $122-186$ & 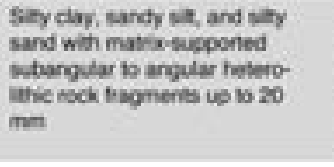 & 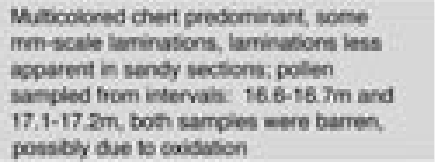 \\
\hline $\begin{array}{l}\text { 5- Prik clarew all } \\
\text { rone }\end{array}$ & $\begin{array}{c}18.6-29.0 \\
\text { te sample } 25 \mathrm{~m}\end{array}$ & 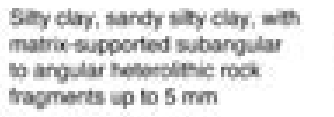 & $\begin{array}{l}\text { Multiceloned chert preseminart; wet } \\
\text { rounded sund dominartly quartr: some } \\
\text { mm-scale laminations }\end{array}$ \\
\hline $\begin{array}{l}6 \text { - Peddiah and } \\
\text { boun mabix } \\
\text { supported none }\end{array}$ & 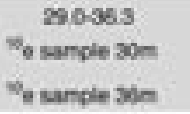 & $\begin{array}{l}\text { Sandy sily clay with matro } \\
\text { supported subangular io } \\
\text { angular holeroletic rocks } \\
\text { hagments up to } 10 \mathrm{~mm}\end{array}$ & 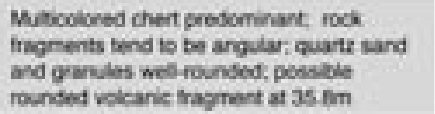 \\
\hline $\begin{array}{l}\text { 7- Nhernating reddieh - } \\
\text { bucens muerk } \\
\text { supported and dast } \\
\text { supported nones }\end{array}$ & 36351.6 & 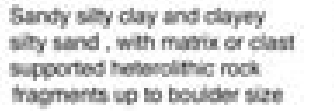 & 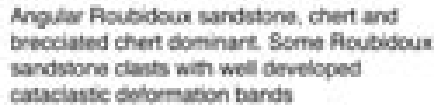 \\
\hline benom of hole & 51.5 & & \\
\hline
\end{tabular}

Table 1: Descriptions of zones in doline fill in drill hole OZ-2 with locations of ${ }^{10} \mathrm{Be}$ sample horizons. 
chemistry and AMS measurement can be found in Bierman et al. (2002).

Samples from 4 intervals in the core were collected from depths of 8.6, 25, 30, and 36 meters for ${ }^{10} \mathrm{Be}$ analysis (Table 1). The ${ }^{10} \mathrm{Be}$ concentrations for these samples are shown on Fig. 8. The observed concentrations are similar to those in Ozark Plateau soils (Pavich, unpublished data). If sediment with a uniform concentration of adsorbed ${ }^{10} \mathrm{Be}$ were added slowly to the doline over millions of years, the depth profile would exhibit an exponential decrease of ${ }^{10} \mathrm{Be}$ due to radioactive decay. Instead, there is no systematic change in ${ }^{10} \mathrm{Be}$ concentration with depth, suggesting that accumulation from local soils has occurred recently; i.e., in the middle to late Quaternary.

\section{DISCUSSION}

The loess found in the doline fill of zone 1 was originally deposited 22,000 to 12,500 years B.P. However, this material has been mobilized and redeposited. The TL data indicate a redeposition age of from 7.6 to 4.3 thousand years B.P, and establishes a minimum age for material below the top 1 meter of the doline fill (zone 1). The underlying alteration of the reddish-brown clayey silt zone (zone 2) occurred post-depositionally and is approximately 125,000 to 75,000 years old; thus the minimum age for the doline fill from zone 2 to zone 6 is constrained as Illinoian (Riss) or older.

The ${ }^{10} \mathrm{Be}$ data from zones 3, 5, and 6 suggest that all of the material filling the doline has been accumulated since the Middle to Late Quaternary. X-ray diffraction analyses of clays throughout the doline fill indicate that they consist of sub-equal amounts of kaolinite and illite, consistent with terrestrial weathering, which has been predominant in the area since the Pennsylvanian.

The bedrock on the Ozark Plateaus has been exposed to subaerial weathering and erosion since the late Paleozoic, limiting the maximum possible age of karstification and subsequent doline filling to the Pennsylvanian. All of the upland topography is covered by a residuum that in some places exceeds 50 meters in thickness. In the study area, where the bedrock is Lower Ordovician in age, this residuum is derived chiefly from insoluble weathering products of preexisting overlying bedrock units of Ordovician, Mississippian, and Pennsylvanian age. Pebbles of black, maroon, and red chert recovered from zone 4 are residue of relic Mississippian rocks that once covered the area.

Although the data acquired from study of this particular doline fill indicate a middle to late Quaternary age, this merely constrains the age of the collapse of the underlying cave. There is still potential for the initial development and age of the cave systems in the southern Ozarks of Missouri to be much older. Studies of other cave deposits in the Ozark may result in different findings and support interpretations of older ages of karstification. The difficulty will be in finding preserved segments of the karst system which contain deposits with measurable evidence of their age.

Data collected by studying collapse doline fills are valuable sources of information on the geologic and geomorphic history of karst areas as they record local depositional history from a discrete moment in the past until the present. These doline fills may preserve sediments derived from older rock units that have been removed from the ground surface by erosion and no longer exist locally. In addition, the age of the fill gives some control over determination of the minimum age of the underlying cave system. A multidisciplinary approach to the study provides a variety of data for use in interpretation of the post-collapse history of the doline. Traditional physical analysis of doline fill sediments can provide a description of the sediment and a relative sequence of sedimentary events, but it is necessary to employ absolute and/or relative dating techniques to verify any assumptions 
made. Cosmogenic ${ }^{10} \mathrm{Be}$ and thermoluminescence dating techniques can be valuable tools for studying karst systems. Both methods provide absolute time constraints on the deposition of sediments derived from surfaces exposed to sunlight. Thus, they can help constrain the age and rates of allogenic sediment input into dolines and sediment movement through cave systems.

\section{REFERENCES}

Bierman, P.R., Caffee, M.W., Davis, P.T., Marsella, K., Pavich, M., Colgan, P., Mickelson, D., and Larsen, J., 2002, Rates and timing of earth surface processes from in situ-produced cosmogenic Be-10, in: Grew, E.S., editor, Beryllium: Mineralogy, Chemistry and Geochemistry, Reviews in Mineralogy and Geochemistry, v. 50, p. 147-205.

Erickson, H.K., Spooner, J.D., Wronkiewicz, D.J., and Harrison, R.W., 2002, X-ray powder diffraction analysis of clay recovered from Big Spring Sink, Missouri. 2002 Missouri Academy of Sciences annual meeting, April 19, 2002.

Forman, S.L., Pierson, J., and Lepper, K., 2000, Luminescence geochronology. pp. 157-176 In: Noller, J.S., Sowers, J.M., and Lettis, W.R. (Eds.), 2000, Quaternary Geochronology - Methods and Applications. American Geophysical Union, AGU Reference Shelf, 4, Washington, D.C.. $582 \mathrm{pp}$.

Orndorff, R.C., Weary, D.J., and Harrison, R.W., 2003: The role of sandstone in the development of an Ozark karst system, southeastern Missouri - Geological Society of America Abstracts with Programs, v. 35, no. 6., 19-5.

Orndorff, R.C., Weary, D.J., and Šebela, S., 2002, Geologic framework of the Ozarks of south-central Missouri; contributions to a conceptual model of karst - Missouri Speleology, vol.42, no.1-2, pp.1-8, 2002.

Thompson, T.L., 1995, The stratigraphic succession in Missouri: Missouri Department of Natural Resources, Division of Geology and Land Survey, v. 40, 2d ser., 189 pp.

Weary, D.J., and Schindler, J.S., 2004, Geologic map of the Van Buren South quadrangle, Carter County, Missouri: U.S. Geological Survey Geologic Investigations Map I-2803, scale 1: 24,000 .

Willman, H. B., and J. C. Frye, 1970, Pleistocene Stratigraphy of Illinois: Illinois State Geological Survey Bulletin 94, plate 1, scale 1:500,000.

Wintle, A.G., and Huntley, D.J., 1982, Thermoluminescence dating of sediments: Quaternary Science Reviews, v. 1, 31-53. 
